\title{
A proteção jurídica da empresa inovadora na pendência de pedido de patente de medicamento no Direito brasileiro
}

\author{
JÓNATAS E.M. MACHADO' \\ PAULO NOGUEIRA DA COSTA ${ }^{2}$
}

\section{Introdução}

Os sistemas de patentes estão concebidos como uma solução de compromisso entre duas considerações políticas concorrentes: por um lado, pretende-se proporcionar incentivos suficientes para encorajar a inovação e o desenvolvimento de invenções novas e socialmente úteis. Por outro lado, visa-se assegurar que tais invenções sejam disponibilizadas ao público a um preço acessível.

A patente cria algo como um monopólio temporário a favor do inventor, permitindo-lhe colher os benefícios patrimoniais da sua criatividade e, se for o caso, recuperar os custos do investimento que por ele ou por outros investidores haja sido realizado na atividade de pesquisa e desenvolvimento que possibilitou a invenção. Ao mesmo tempo, ela promove a divulgação e partilha do conhecimento inovador e inventivo, possibilitando a comercialização dos inventos e o progresso científico. Estas são as principais virtualidades do sistema de patentes ${ }^{3}$.

Uma questão pertinente, que emerge no quadro jurídico de proteção da empresa inovadora, é a que se prende com saber se e em que circunstâncias é que mesmo durante a

1 Professor Associado com Agregação da Faculdade de Direito da Universidade de Coimbra e da Universidade Autónoma de Lisboa.

2 Professor Auxiliar da Universidade Autónoma de Lisboa, Professor Adjunto do Instituto Superior de Contabilidade e Administração de Lisboa e Diretor e Coordenador Científico do Ratio Legis.

3 BAIR, Stephanie Plamondon - The Psychology of Patent Protection. In Connecticut Law Review. Hartford. ISSN 0010-6151. V. 48, N. ${ }^{\circ}$ 2, 2015, 247 ss. 
pendência de pedidos de patente pode haver lugar à proteção jurídica de direitos exclusivos patentários através de providências preliminares de tutela cautelar, à luz de considerações respeitantes ao direito da propriedade intelectual, à tutela da concorrência leal e justa e à garantia de uma proteção jurídica efetiva e sem lacunas.

É essa questão que analisamos no presente estudo, circunscrevendo-a à realidade jurídica brasileira e tendo especialmente em conta as especificidades da indústria farmacêutica e das patentes de medicamentos.

\section{Propriedade intelectual}

\section{A. Inovação e investimento}

Apesar da subsistência de importantes focos de inovação individual ${ }^{4}$, uma análise contemporânea do conhecimento especializado mostra que se encontra há muito superado o paradigma do inventor genial a trabalhar isoladamente na cave ou na garagem da sua casa (v.g. Bell, Edison, Jobs, Gates). Embora o processo inventivo tenha evoluído largamente graças ao esforço e à criatividade individuais, a versão moderna da invenção consubstancia frequentemente um esforço de dimensão industrial multidisciplinar, cumulativo e cooperativo iniciado e gerenciado por empresas de dimensão variável, comumente de dimensão transnacional 5 .

A indústria farmacêutica é hoje um exemplo paradigmático dessa realidade. A sua existência serve o interesse público internacional da promoção da saúde diante dos emergentes riscos sanitários que se colocam à escala global ${ }^{6}$. Daí a importância de conformar o sistema de patentes de forma a incentivar a inovação no setor do medicamento.

O sistema regulatório deve responder a duas preocupações fundamentais. Uma, prende-se com o elevado custo que as empresas têm que suportar na pesquisa para o desenvolvimento de novos medicamentos. Nesta matéria existem várias estimativas. Algumas delas, já com algum tempo, indicam que o custo da introdução de um novo medicamento no mercado se situa entre os 800 milhões e os 1,3 mil milhões de dólares ${ }^{7}$. Alguns estudos mais

4 TORRANCE, Andrew W.; HIPPEL, Eric von - The Right to Innovate. In Michigan State Law Review. East Lansing. ISSN 0026-2234. N. ${ }^{\circ} 793,2015,793$ ss.

5 ALI, Feroz - Technical Speech: Patents, Expert Knowledge, and the First Amendment. In Minnesota Journal of Law, Science \& Technology. Minneapolis. ISSN 1552-9541. V. 17, N. ${ }^{\circ}$ 1, 2016, 277 ss.

6 ROSENBAUM, Sara - The Globalization of Health Care. In Tulsa Law Review. Tulsa. ISSN 1538-9979. V. 50, N. ${ }^{\circ} 2$, 2015, 607 ss.

7 GAUDRY, Kate S. - Uncharted Territories of the Patent-Restoration Due-Diligence Challenge. In Food and Drug Law Journal. Washington. ISSN 1064-590X. V. 66, N. ${ }^{\circ}$ 1, 2011, 121 ss.; WEILBAECHER, Ann - Diseases Endemic in 
recentes apontam para valores substancialmente superiores. Para recuperar esses elevados custos, as empresas farmacêuticas dependem acima de tudo da disposição e da capacidade dos consumidores para adquirir os medicamentos por elas produzidos. Outra preocupação, prende-se com o tempo que as empresas farmacêuticas têm que gastar em ensaios pré-clínicos e clínicos antes de obterem autorização de introdução do medicamento no mercado. As estimativas apontam para um tempo médio de entre 12 a 15 anos $^{8}$. De um modo geral, quanto mais inovador um medicamento pretende ser, maior é o tempo despendido em ensaios pré-clínicos e clínicos. Os custos de oportunidade em dinheiro e tempo que as empresas têm que suportar são enormes, tanto mais quanto é certo que o desfecho da pesquisa e dos ensaios clínicos é incerto, como o é também o sucesso comercial do medicamento.

O sistema de patentes deve dar uma resposta adequada a esta complexa realidade, incentivando as empresas a suportar estes custos com uma expectativa plausível de retorno. Por um lado, deve dar uma garantia de direitos exclusivos limitados sobre os seus medicamentos produzidos. Sem essa proteção de patentes exclusivas, muitas empresas não conseguiriam reunir e investir os fundos necessários para desenvolver novos medicamentos. Por outro lado, o sistema de patentes não deve ser visto e operado de forma isolada, mas em interação com o sistema sanitário de autorização de introdução dos medicamentos no mercado.

\section{B. $O$ sistema de patentes $\mathrm{e} o$ direito à saúde}

$\mathrm{O}$ direito à saúde representa uma dimensão concretizadora fundamental dos direitos à vida, à integridade física e psíquica e ao bem-estar individual e social. Na sua qualidade de direito humano, internacional e constitucionalmente protegido, o direito à saúde é uma condição de desenvolvimento económico, social e cultural das populações. No artigo $25{ }^{\circ}$ da Declaração Universal dos Direitos do Homem, de 1948, lê-se:

"[t]oda a pessoa tem direito a um nivel de vida suficiente para lhe assegurar è sua família a saúde e o bem-estar, principalmente quanto à alimentação, ao vestuário, ao alojamento, à assistência médica e ainda quanto aos serviços sociais necessários, e tem direito à segurança no desemprego, na doença, na invalidez, na viuvez, na velhice ou noutros casos de perda de meios de subsistência por circunstâncias independentes da sua vontade."

Developing Countries: How to Incentivize Innovation. In Annals of Health Law. Chicago. ISSN 1075-2994. V. 18, N. ${ }^{\circ}$ 2, 2009, $281 \mathrm{ss}$.

8 WEILBAECHER, Ann - Diseases Endemic in Developing Countries: How to Incentivize Innovation. In Annals of Health Law. Chicago. ISSN 1075-2994. V. 18, N. ${ }^{\circ} 2,2009,281$ ss. 
Particularmente importante, neste contexto, é o Comentário Geral 14 que, no âmbito das Nações Unidas, pretende densificar o direito à saúde. Ele manifesta uma visão abrangente e realista deste direito humano fundamental, salientando a íntima relação com outros direitos humanos constantes dos instrumentos internacionais, como sejam o direito à alimentação, à habitação, ao trabalho, à educação, à dignidade humana, à vida, à não discriminação, à igualdade, a não ser torturado, à privacidade, ao acesso à informação, as liberdades de associação, reunião e movimento etc.

Este entendimento amplo e relacional do direito à saúde afigura-se do maior relevo, na medida em que estabelece uma relação complexa entre o direito à saúde e outras variáveis importantes associadas à pobreza e ao subdesenvolvimento. Ele sublinha a importância que o combate à pobreza, em domínios como a nutrição, a habitação ou o saneamento básico, podem desempenhar na promoção da saúde pública, especialmente nas zonas rurais dos Estados menos desenvolvidos.

Destaca-se igualmente a importância da prevenção e do tratamento das doenças epidémicas, endémicas, profissionais e outras, bem como a luta contra essas doenças, juntamente com a criação de condições que assegurem a todos assistência médica e serviços médicos no caso de enfermidade. Além disso, reclama-se a mobilização de esforços não apenas dos Estados, mas de toda a sociedade civil, nacional e internacional, num compromisso público, simultaneamente moral e jurídico, de promoção da igualdade e da justiça no sector da saúde. Em todo o caso, a proteção e promoção do direito à saúde depende da ação estadual em múltiplos domínios e sobre diversos fatores, como sejam, por exemplo, a melhoria das condições higiénicas do trabalho, o saneamento básico ou a proteção do ambiente.

A realização do direito à saúde, nas suas dimensões individuais e coletivas, supõe, naturalmente, a acessibilidade dos medicamentos às populações. Porque assim é, a proteção dos direitos patentários da indústria farmacêutica é por vezes desvalorizada como uma inaceitável compressão do direito à saúde dos indivíduos e do bem jurídico da saúde pública, alegadamente favorecendo, de maneira insensível, a propriedade intelectual e os interesses económicos empresariais.

Contudo, a perspetiva abrangente de realização do direito à saúde adotada pelo Comentário Geral 14 refuta a qualquer associação que rapidamente se queira fazer entre a garantia do direito à saúde e a introdução de medicamentos genéricos e similares, à custa dos direitos de propriedade intelectual das empresas farmacêuticas de referência - responsáveis, em última análise, pelo desenvolvimento e pela disponibilização de novos medicamentos.

Assim é, quer essa associação resulte de uma orientação política deliberada - mais ou menos oportunista - quer seja simplesmente o resultado de deficiências e más práticas administrativas, no plano institucional e processual (v.g. opacidade; atraso excessivo no 
exame dos pedidos de patentes). Semelhante associação conduziria, a médio prazo, a uma significativa diminuição da quantidade, qualidade e novidade dos medicamentos, com um impacto negativo na saúde das populações.

Os medicamentos farmacêuticos constituem um poderoso instrumento da medicina convencional. Os mesmos salvam vidas, aliviam o sofrimento, aumentam a longevidade e melhoram a qualidade de vida de quantos a eles têm acesso. Isso só é possível graças à atividade de pesquisa e desenvolvimento na criação de novos medicamentos. Alguma dessa pesquisa é levada a cabo por laboratórios públicos ou por universidades. No entanto, uma parte substancial da mesma é realizada pela indústria farmacêutica.

A indústria farmacêutica caracteriza-se pela sua dependência de pesquisa científica intensiva, carecida de uma disciplina jurídica adequada a essa sua natureza. Essa característica essencial da indústria farmacêutica não pode ser descurada, nem pelo direito internacional, nem pelos direitos nacionais. É unicamente através da atividade sistemática de pesquisa e desenvolvimento de novos medicamentos que se pode pretender, com alguma plausibilidade, enfrentar os problemas de saúde pública e as novas emergências sanitárias de natureza global.

Disso depende a proteção do direito à saúde a médio e longo prazo. E isso só é possível mediante a criação e preservação de uma estrutura de incentivos favorável à criação de informação e à acumulação de conhecimento. Essa orientação terá, naturalmente, inevitáveis corolários institucionais, nomeadamente no que diz respeito ao procedimento administrativo de apreciação dos pedidos de registo de patente.

Uma política do medicamento constitucionalmente adequada procurará encorajar o investimento sustentado em investigação e desenvolvimento de novos medicamentos de elevada qualidade técnica e científica, conjugando isso com soluções que permitam o acesso generalizado aos medicamentos num mercado competitivo, eventualmente corrigido, nas suas falhas, por mecanismos de justiça social ${ }^{9}$.

\section{Propriedade intelectual e registo da patente}

\section{A. Direito à concessão da patente}

Na sua qualidade de direito fundamental, o direito de propriedade intelectual encontra-se disciplinado juridicamente de maneira a garantir a sua eficácia, de acordo com princípios

9 MACHADO, Jónatas; RAPOSO, Vera - Direito à Saúde e Qualidade dos Medicamentos: Proteção dos Dados de Ensaios Clínicos Numa Perspetiva de Direito Brasileiro, Comparado e Internacional. Coimbra: Almedina, 2010. 
constitucionais de legalidade, igualdade, proibição do arbítrio, previsibilidade, segurança jurídica e proteção da confiança. Assim se compreende a consagração de um verdadeiro direito à concessão da patente uma vez verificados os respetivos pressupostos legais. Isso mesmo decorre do artigo $6 .^{\circ}$ da Lei de Propriedade Industrial do Brasil (LPIB) ${ }^{10}$. Aí se prescreve:

"Ao autor de invento ou modelo de utilidade será assegurado o direito de obter a patente que lhe garanta a propriedade, nas condições estabelecidas nesta Lei."

Esta disposição, decorrendo dos compromissos assumidos no âmbito da Rodada do Uruguai e da Organização Mundial de Comércio (OMC), está em plena sintonia com o artigo 27. ${ }^{\circ}$ do Agreement on Trade-Related Aspects of Intellectual Property Rights (TRIPS), onde se prescreve a disponibilização de patentes, sem discriminação, para as invenções de produtos e processos em todos os domínios da tecnologia, verificados os requisitos da novidade, do salto inventivo e da aplicação industrial, embora com algumas restrições de ordem pública ou moralidade. Trata-se de um direito subjetivo que impõe aos poderes públicos a concessão de uma patente em termos que afastam qualquer voluntarismo, discricionariedade ou arbitrariedade.

Muitas das disposições do TRIPS foram elaboradas com o objetivo de harmonizar os diversos regimes internacionais e nacionais de patentes. Por esse motivo, o direito nacional da propriedade intelectual deve ser interpretado e aplicado em conformidade com a letra e o espírito do TRIPS ${ }^{11}$.

\section{B. Registo da patente}

Seguindo uma orientação desde há muito radicada no direito das patentes, o Artigo $8 .^{\circ} \mathrm{da}$ LPIB, dispõe:

"É patenteável o invento que atenda aos requisitos de novidade, atividade inventiva e aplicação industrial."

Estabelecem-se, assim, os três requisitos fundamentais da patenteabilidade, sobre os quais nos debruçaremos na estrita medida em que isso seja útil à discussão da questão em apreço. Cada um deles deu origem à sua própria linha doutrinal de invalidação das patentes e que, no seu conjunto, as mesmas sustentam as problemáticas da patenteabilidade do

10 Lei n. ${ }^{\circ}$ 9279/96, de 14-5, com sucessivas alterações.

11 CAMPBELL, Randy L. - Global Patent Law Harmonization: Benefits and Implementation. In Indiana International \& Comparative Law Review. Indianapolis. ISSN 1061-4982. V. 13, N. ${ }^{2}$, 2003, 605 ss. 
objeto e da completude da invenção. No entendimento dos três requisitos, assume especial importância o WIPO Patent Drafting Model.

\section{Significado material}

\section{a) Direito exclusivo}

O Artigo $5 \cdot{ }^{\circ}$ XXIX da Constituição Federal do Brasil de 1988 consagra a proteção da propriedade intelectual. Aí se dispõe:

"a lei assegurará aos autores de inventos industriais privilégio temporário para sua utilização, bem como proteção às criações industriais, à propriedade das marcas, aos nomes de empresas e a outros signos distintivos, tendo em vista o interesse social e o desenvolvimento tecnológico e económico do Pais;"

Nesse mesmo diapasão, o artigo $2 .^{\circ}$ da LPIB relaciona a concessão de patentes de invenção à prossecução do interesse social e do desenvolvimento tecnológico e económico do país, não deixando de estabelecer uma conexão interna entre propriedade industrial, patentes e a repressão da concorrência desleal, aspeto que assume relevância de monta na discussão subsequente.

A dignidade constitucional do direito de propriedade intelectual (latu sensu) é inteiramente compreensível, atenta a relevância económica, social e cultural do conhecimento científico e do progresso tecnológico ${ }^{12}$. Da Constituição resultam importantes implicações substantivas e processuais para a produção, interpretação e aplicação do direito infraconstitucional, no que toca à promoção e proteção da atividade intelectual e criativa. É neste quadro que deve ser interpretado e aplicado o artigo $42 . .^{\circ}$ da LPIB, que determina:

"A patente confere ao seu titular o direito de impedir terceiro, sem o seu consentimento, de produzir, usar, colocar à venda, vender ou importar com estes propósitos:

I - produto objeto de patente;

II - processo ou produto obtido diretamente por processo patenteado.

$\S 1 \div$ Ao titular da patente é assegurado ainda o direito de impedir que terceiros contribuam para que outros pratiquem os atos referidos neste artigo.

12 Sobre as implicações da natureza constitucional do direito da propriedade intelectual, veja-se MURRAY, Kali N. - Constitutional Patent Law: Principles and Institutions. In Nebraska Law Review. Lincoln. ISSN 0047-9209. V. 93, N. ${ }^{\circ} 4,2015,901$ ss. 
$\S 2 .{ }^{\circ}$ Ocorrerá violação de direito da patente de processo, a que se refere o inciso II, quando o possuidor ou proprietário não comprovar, mediante determinação judicial específica, que o seu produto foi obtido por processo de fabricação diverso daquele protegido pela patente."

Resulta do preceito legal em presença que a patente confere ao seu titular o direito exclusivo temporário de beneficiar da comercialização do seu invento. Esta posição jurídica de monopólio tem como contrapartida a divulgação pública dos conhecimentos incorporados na invenção, uma vez transcorrido o prazo de validade da patente. Depois dessa data, os conhecimentos serão do domínio público.

Trata-se de uma troca estruturada em termos de quid pro quo: o inventor divulga o conhecimento e o Estado concede-lhe um monopólio temporário ${ }^{13}$. Este monopólio temporário está longe de ser uma anomalia sistemicamente disfuncional na ordem jurídica. Com efeito, a patente é tão monopolista ou exclusivista como o direito de propriedade, o contrato de arrendamento ou o contrato de trabalho, posto que em todos estes instrumentos jurídicos é garantida uma medida significativa de exclusividade e imunidade relativamente às forças de mercado ${ }^{14}$.

O direito das patentes assenta no pressuposto de que a capacidade de excluir temporariamente outros de produzir ou utilizar uma invenção constitui uma forte motivação para incentivar o inventor a inovar e a divulgar os segredos de sua invenção.

\section{b) Incentivo à inovação e ao investimento}

As patentes protegem os interesses dos fabricantes de medicamentos de primeira colocação no mercado, ao mesmo tempo em que protegem concorrentes que desejam criar drogas formicamente distintas. As patentes impedem a imitação, não a inovação. Uma patente sobre um composto existente proíbe empresas rivais de fabricar produtos baseados em compostos químicos semelhantes. As imitações, mesmo quando finalmente introduzidas no final do prazo das patentes, não expandem as opções de tratamento disponíveis para os consumidores. Na melhor das hipóteses, eles levam a medicamentos semelhantes mais baratos, o que não é despiciendo.

13 Este entendimento tem sido acolhido na jurisprudência do Supremo Tribunal norte-americano, como se pode ver, por exemplo, no caso Festo Corporation, Petitioner V. Shoketsu Kinzoku Kogyo Kabushiki Co., Ltd., Et Al. 535 U.S. 722 ; 122 S. Ct. 1831. J. E. M. AG Supply, Inc., Dba Farm Advantage, Inc., Et Al., Petitioners V. Pioneer Hi-Bred International, Inc. 534 U.S. 124; 122 S. Ct. 593; 151 L. Ed. 2 d 508.

14 SINGER, Joseph William - Property as the Law of Democracy. In Duke Law Journal. Durham. ISSN 1939-9111. V. 63, N. ${ }^{\circ}$ 6, 2014, 1325 ss; a mesma ideia é sublinhada por CARVALHO, Nuno Pires de - The TRIPS Regime of Patent Rights. 2. ${ }^{\mathrm{a}}$ ed. The Hague: Kluwer Law International, 2005, 156. 
A concessão do registo da patente serve uma importante função de interesse público. Por este motivo, o problema do prazo de proteção das empresas inovadoras de referência constitui um problema recorrente. A necessidade de garantir um adequado retorno para o seu investimento manifesta-se nas diferentes soluções que vão sendo desenhadas, em diversos quadrantes, no direito internacional, supranacional e nacional.

No direito brasileiro, à semelhança do que sucede com muitos outros países, esse compromisso assenta na concessão ao inventor de direitos exclusivos de comercialização do seu produto durante 20 anos, que corresponde ao prazo de vigência da patente de invenção a partir da data do depósito, nos termos previstos no artigo $40 .^{\circ}$ da LPIB.

Trata-se da solução que decorre dos compromissos assumidos no âmbito da Rodada do Uruguai e da Organização Mundial de Comércio, já que o artigo $33 .^{\circ}$ do TRIPS estabeleceu esse mesmo prazo para a vigência da patente. O legislador internacional entendeu que esse período é suficientemente longo para que os inventores pudessem recuperar os seus custos de pesquisa e desenvolvimento e obter lucros, sem privar o público de versões mais acessíveis dessas invenções em virtude de uma duração desordenada e excessiva.

O § único do artigo $40 .^{\circ}$ da LPIB dispõe que esse prazo nunca será inferior a 10 anos a partir do momento da concessão da patente, embora admita derrogações a esta regra no caso de o Instituto Nacional da Propriedade Industrial (INPI) estar impedido de proceder ao exame de mérito do pedido, por pendência judicial comprovada ou por motivo de força maior. Parte-se, portanto, do princípio de que o normal é que o INPI proceda ao exame do mérito do pedido em tempo razoável.

\section{c) Repressão da concorrência desleal}

Num mercado aberto, competitivo e não falseado, estruturado com base nos princípios da liberdade, da igualdade e da neutralidade económica do Estado, os consumidores podem beneficiar da maior quantidade e melhor qualidade de bens e serviços propiciados por uma economia de mercado funcional e saudável. O direito da concorrência assenta num postulado de autonomia empresarial, devendo considerar-se ilegítimas todas as condutas de mercado que, direta ou indiretamente, atual ou potencialmente, atentem contra ele.

Do Estado requer-se que garanta o respeito pelos princípios de liberdade e igualdade das empresas e que se abstenha de desnivelar o terreno do jogo competitivo, favorecendo umas empresas em detrimento de outras. Só garantindo o funcionamento concorrencial dos mercados, num quadro de liberdade e de igualdade, é possível assegurar a maximização da eficiência económica ${ }^{15}$.

15 MOTTA, Massimo - Competition Policy: theory and practice. Cambridge, New York: Cambridge University Press, 2004, pp. 17 ss.; VAHEESAN, Sandeep - The Evolving Populisms of Antitrust. In Nebraska Law Review. Lincoln. ISSN 0047-9209. V. 93, N. ${ }^{\circ} 2,2014,370$ ss. 
Este aspeto assume grande importância no contexto da proteção da propriedade intelectual. Ao conceder um monopólio temporário ao inventor, com os correspondentes direitos exclusivos, a patente constitui uma restrição ao direito de livre concorrência no mercado. No entanto, trata-se de uma restrição justa e adequada, na medida em que assenta numa ponderação equilibrada e proporcional entre a liberdade de iniciativa económica privada e a liberdade de concorrência, por um lado, e o interesse público na promoção da inovação científica e tecnológica e do investimento em atividades de pesquisa e desenvolvimento.

No âmbito da indústria farmacêutica, há lugar para uma medida razoável de concorrência económica entre empresas inovadoras e criadores de medicamentos de referência e empresas de medicamentos similares e genéricos, contribuindo para a redução do preço dos medicamentos com benefícios para os doentes e para os contribuintes que financiam o sistema de saúde universal ${ }^{16}$. Por essa via podem ser dados passos significativos na realização do direito à saúde.

Este direito humano é mais bem servido através da procura de um ponto ótimo entre as coordenadas da promoção do investimento na pesquisa de novos medicamentos e do aumento da concorrência de medicamentos genéricos no mercado de medicamentos farmacêuticos, reduzindo assim os preços dos medicamentos e os custos dos consumidores de medicamentos. No entanto, mesmo aí essa concorrência deve ser leal, não podendo ser falseada ou distorcida.

\section{A autoridade de concessão de patente}

\section{a) Generalidades}

A proteção dos direitos de propriedade industrial tem incontornáveis implicações institucionais. As mesmas aplicam-se não apenas ao INPI, mas a todas as entidades que, nos vários países, apreciam os pedidos de concessão de patentes. Elas decorrem, em boa medida, da juridicidade e legalidade da administração e do direito fundamental à boa administração. O objetivo é assegurar a adequada ponderação dos direitos fundamentais e do interesse público.

Em causa está a garantia do processamento administrativo dos pedidos de concessão de patentes de acordo com exigências constitucionais de legalidade, igualdade, equidade, justiça, participação, decisão tempestiva, fundamentação e responsabilidade dos danos causados por ações e omissões. Sem esquecer a existência de meios de tutela jurisdicional

16 COLLEEN, Kelly - The Balance Between Innovation and Competition: The Hatch-Waxman Act, the 2003 Amendments, and Beyond. In Food and Drug Law Journal. Washington. ISSN 1064-59oX. V. 66, N. ${ }^{\circ}$ 3, 2011,417 ss. 
cautelar e definitiva. Trata-se de exigências substantivas e processuais sobejamente conhecidas, cuja elaboração teórica e dogmática extravasa o âmbito do presente estudo.

Neste momento importa apenas alguns aspetos geralmente válidos respeitantes à competência técnica, à transparência e objetividade e à independência e imparcialidade, geralmente válidos para todas as instituições com responsabilidades no domínio da concessão de patentes ${ }^{17}$.

\section{b) Competência técnica}

A concessão de patentes exige o estabelecimento de uma entidade dotada de competência técnica. É necessário um sólido conhecimento do estado da arte nos vários domínios da ciência e da técnica para decidir sobre a presença de novidade, atividade inventiva e aplicação industrial. Também é preciso dominar a linguagem científica e jurídica para aferir da precisão e determinabilidade das reivindicações e da sua consistência com a descrição escrita. A quantidade e qualidade dos examinadores e do exame de patentes repercute-se, inevitavelmente, no nível de litigiosidade subsequente ${ }^{18}$.

A averiguação dos requisitos de patenteabilidade e a avaliação das reivindicações é uma tarefa de grande complexidade e responsabilidade, de que depende a delimitação dos direitos de propriedade intelectual dos inventores, com assinaláveis consequências no equilíbrio entre os interesses da inovação e da concorrência.

A promoção do desenvolvimento científico, técnico e económico do país requer uma atenção ao risco de insuficiente rigor técnico no processo de apreciação dos pedidos, suscetível de gerar incerteza jurídica e litigância judicial. Esta questão é indissociável da problemática da garantia dos recursos humanos, materiais e técnicos necessários e adequados ao competente, rigoroso e tempestivo processamento dos pedidos de patentes ${ }^{19}$.

\section{c) Transparência e objetividade}

A atuação das autoridades competentes para a concessão de patentes deve pautar-se por princípios de transparência e objetividade, ainda que sem comprometer as exigências normais de sigilo e confidencialidade. A decisão deve ser objetiva, fundamentada e controlável. A lei determina que a patente só deve ser concedida se houver novidade, salto inventivo

17 WASSERMAN, Melissa F. - What Administrative Law can Teach the Trademark System. In Washington University Law Review. St. Louis. ISSN 2166-8000. V. 93, N. ${ }^{\circ} 6,2016,1511$ ss.

18 TU, Shine - Patent, Examiners and Litigation Outcomes. In Stanford Technology Law Review. Stanford. ISSN 1098-4267. V. 17, 2014, 507 ss.

19 QUILLEN JR., Cecil D.; WEBSTER, Ogden H. - Continuing Patent Applications and the U.S. Patent and Trademark Office-Updated". In The Federal Circuit Bar Journal. Washington. ISSN 1055-8195. V. 15, N. 4, 2006, 635 ss. 
e aplicação industrial. Igualmente importante é a suficiência descritiva e a congruência entre a descrição da invenção e as reivindicações da patente.

O processo de decisão deve ser transparente e objetivo, do ponto de vista factual, lógico, técnico e jurídico. Ou estão verificados os requisitos da patenteabilidade e é concedida a patente ou não estão verificados os requisitos e não é concedida a patente. As decisões tomadas ou omitidas têm grandes implicações nos domínios da invenção, da concorrência, do desenvolvimento económico ou da proteção da saúde.

\section{d) Independência e imparcialidade}

Das autoridades com competência para a concessão de patentes espera-se que atuem de forma independente e imparcial. A proteção da propriedade intelectual deve ser levada a cabo de acordo com o quadro normativo pertinente, com princípios de tratamento nacional, igualdade, não discriminação e observância do direito internacional relevante, sem intromissões do poder político ou económico. O direito deve impedir qualquer forma de enviesamento institucional (institutional bias) ou a captura destas entidades (agency capture) pelas empresas interessadas, sejam elas grandes ou pequenas, nacionais ou estrangeiras ${ }^{20}$. Do funcionamento da autoridade administrativa da propriedade industrial não podem resultar distorções à concorrência, em benefício de algumas empresas e prejuízo de outras.

\section{e) Diligência regulatória}

As autoridades de concessão das patentes devem pautar a sua atuação por critérios de eficiência, economicidade e celeridade. O prolongamento excessivo do processo administrativo de apreciação do pedido de registo de patente diminui substancialmente a vida útil da patente quando a mesma venha a ser concedida, constituindo um forte desincentivo à inovação e frustrando os objetivos prosseguidos pela legislação nacional de propriedade industrial e pelo TRIPS.

O atraso irrazoável e desproporcional na apreciação dos pedidos de registos de patente introduz incerteza e insegurança jurídica no sistema de proteção patentária, podendo ter consequências económicas deletérias não apenas para os requerentes das patentes - traduzidas aqui na perda de atratividade para financiadores e investidores - mas igualmente para a comunidade técnica e científica globalmente considerada - que perderá confiança no sistema de patentes e verá destruída a estrutura de incentivos à pesquisa e invenção - e, por consequência, para toda a sociedade - que desse modo verá frustrado o desiderato constitucional de promoção do desenvolvimento científico, tecnológico, económico e social do país.

20 Alertando para esta questão, WASSERMAN, Melissa F. - What Administrative Law can Teach the Trademark System. In Washington University Law Review. St. Louis. ISSN 2166-8000. V. 93, N. 6, 2016, 1511 ss., 1571 ss. 


\section{A proteção do inventor entre o depósito e a concessão da patente}

Uma questão que se reveste de grande importância prática prende-se com saber qual a proteção de que goza o inventor no período de tempo entre o depósito do pedido da patente e a decisão final. Para a sua discussão e resolução afiguram-se pertinentes duas ordens de considerações de sinal contrário.

Por um lado, entende-se que em regra essa proteção não pode ser idêntica à que seria conseguida se já tivesse sido registada a patente. O simples depósito de um pedido de patente não pode, por si só, na maioria dos casos, impedir ou travar a inovação e a livre concorrência.

Por outro lado, o inventor também não pode ficar totalmente dependente da maior ou menor morosidade da autoridade administrativa competente. Assim como é verdade a máxima de que justiça retardada é justiça negada (justice delayed is justice denied), também o é que, neste domínio, uma decisão demorada pode redundar, na prática, numa patente negada ${ }^{21}$.

A verdade é que a solução segundo a qual os inventores só poderiam obter compensação pelas infrações verificadas depois da concessão da patente deixava os inventores numa posição de especial vulnerabilidade económica no período entre o depósito do pedido de patente e a decisão definitiva de atribuição, em termos que em larga medida escapavam ao seu controlo.

Para além dos custos económicos e de desmoralização que isso inevitavelmente tinha nos inventores individualmente considerados - sendo que alguns eram na verdade empresas de grande dimensão e com elevadas despesas em pesquisa e desenvolvimento - o impacto negativo em todo o sistema de patentes era tão evidente como intolerável, na medida em que as suas finalidades de incentivo e promoção da inovação e do desenvolvimento científico e tecnológico podiam agora ser facilmente frustradas apenas pelo mau funcionamento das estruturas administrativas competentes.

O direito brasileiro, à semelhança do que sucede com os seus congéneres, garante uma medida de proteção ao inventor entre a publicação do pedido e a concessão da patente. Com efeito, a LPIB dispõe o seguinte:

"Art. 44. Ao titular da patente é assegurado o direito de obter indenização pela exploração indevida de seu objeto, inclusive em relação à exploração ocorrida entre a data da publicação do pedido e a da concessão da patente.

21 FEI, Charleen - Justice Delayed Is Justice Denied? The Principle of Bifurcation in The German Patent Litigation System. In Wake Forest Journal of Business and Intellectual Property Law. Winston-Salem. ISSN 2164-6945. V. 14, N. ${ }^{\circ} 4,2014,619$ ss. 
$\S 1 .^{\circ}$ Se o infrator obteve, por qualquer meio, conhecimento do conteúdo do pedido depositado, anteriormente à publicação, contar-se-á o período da exploração indevida para efeito da indenização a partir da data de início da exploração.

$\S 2 .^{\circ}$ Quando o objeto do pedido de patente se referir a material biológico, depositado na forma do parágrafo único do art. 24, o direito à indenização será somente conferido quando o material biológico se tiver tornado acessivel ao público.

$\S 3 .^{\circ} \mathrm{O}$ direito de obter indenização por exploração indevida, inclusive com relação ao período anterior à concessão da patente, está limitado ao conteúdo do seu objeto, na forma do art. 41 ".

O artigo $44 .^{\circ}$ assegura uma medida de proteção patentária entre a data de publicação do pedido, e nalguns casos antes dela, estipulando o artigo 210..$^{\circ}$ da LPI uma justa compensação a determinar com base no mais generoso de três critérios.

O $\S 3$ do artigo $44 .^{\circ}$ remete para o âmbito das reivindicações e para a necessária congruência que deve existir entre estas e a descrição escrita da invenção. As questões adquirem outra complexidade e delicadeza nas situações, como a que se verifica no caso concreto, em que a autoridade competente para conceder o registo da patente demora um tempo manifestamente irrazoável e desproporcional, em termos suscetíveis de neutralizar significativamente a proteção jurídica que a patente viria a conseguir. Nestes casos, o mau funcionamento da administração impõe custos económicos desproporcionais aos inventores. Quando assim sucede, há que aprofundar a análise.

Como se verá, porém, tal remédio, em diversos casos, como no presente, não é suficiente para prevenir os danos causados, razão pela qual a tutela injuntiva é por vezes necessária.

\section{Atraso na concessão da patente}

A doutrina que acompanha estes problemas de forma continuada e sistemática tem vindo a chamar a atenção para a tendência crescente no sentido do aumento das situações de atraso (backlog) no processo de apreciação de pedidos de patente, com prejuízo para inventores, concorrentes e público em geral, pondo em causa a credibilidade institucional das autoridades de patentes ${ }^{22}$. Trata-se de uma realidade complexa e multifatorial que, longe de se confinar ao Brasil, tem sido referenciada em diversos quadrantes ${ }^{23}$. A mesma veio

22 TU, Sean - Understanding The Backlog Problems Associated With Requests For Continued Examination Practice. In Duke Law \& Technology Review. Durham. ISSN 2328-9600. V. 13, N. ${ }^{\circ} 1,2015,216$ ss.

23 NAQI, Sharick - Comment on Provisional Patent Rights. In Northwestern Journal of Technology and Intellectual Property. Chicago. ISSN 1549-8271. V. 10, N. ${ }^{\circ} 7,2012,595$ ss. 
desequilibrar significativamente a ponderação de interesses realizada entre inovação e concorrência, obrigando ao desenho e à implementação de soluções corretivas de natureza legislativa ou jurisdicional.

Para resolver este problema de forma justa e equilibrada têm sido ensaiadas várias soluções. As mesmas preocupam-se com as restrições ao direito de propriedade intelectual resultantes de falta de diligência regulatória (regulatory due-dilligence) por parte das autoridades administrativas.

Tendo em vista a complexidade do tema e considerando que a realização de uma análise comparada de todos os seus contornos extravasa o âmbito do presente estudo, parece-nos relevante chamar a atenção, ainda que de forma breve e esquemática, para algumas soluções que o direito norte-americano tem apresentado para resolver a questão do impacto do atraso regulatório na proteção patentária.

Pretende-se evidenciar como se procura assegurar a conformidade com os objetivos do sistema de patentes e com o modo como este pondera, de forma razoável e equilibrada, os interesses concorrentes das empresas inovadoras de referência, por um lado, e das empresas de genéricos e similares, por outro.

Nos Estados Unidos a preocupação com a preservação da remuneração dos investimentos em pesquisa e desenvolvimento efetuados pelas empresas farmacêuticas inovadoras manifesta-se, desde logo, no conhecido Hatch-Waxman Act $^{24}$, onde se prevê a extensão das patentes em função de determinados requisitos. Em causa estava a compensação das empresas farmacêuticas de referência pelo encurtamento da proteção patentária que resultava frequentemente da interação regulatória entre a Food and Drugs Administration (FDA) e o Patent and Trademark Office (USPTO).

Às empresas de genéricos passou a ser facultado um processo abreviado de autorização de medicamentos novos - com dispensa de ensaios pré-clínicos e clínicos de demonstração de qualidade, segurança e eficácia - bastando apenas demonstrar a similaridade com um medicamento de referência já autorizado. Ao mesmo tempo, a lei Hatch-Waxman determinou que, para esse efeito, a realização de testes sobre o medicamento genérico não configuraria uma infração da patente do medicamento de referência.

Em contrapartida, às empresas inovadoras era assegurada a extensão do prazo da patente por 2 ou 5 anos, consoante os casos e em função de determinados pressupostos ${ }^{25}$. Por este meio, as empresas farmacêuticas de referência obtinham uma compensação pelo

24 Drug Price Competition and Patent Term Restoration Act of 1984 (Hatch-Waxman Act), Pub. L. No. 98-417, 98 Stat. 1585. 25 Uma descrição detalhada do sistema pode ver-se em BAIR, Stephanie Plamondon - Adjustments, Extensions, Disclaimers, and Continuations: When do Patent Term Adjustments Make Sense?. In Capital University Law Review. Columbus. ISSN 0198-9693. V. 41, N. ${ }^{\circ}$, 2013, 445 ss. 
encurtamento da proteção patentária que resultava, na prática, da demora do processo de autorização de entrada dos medicamentos no mercado junto da FDA, envolvendo múltiplos ensaios pré-clínicos e clínicos. A mesma preocupação com a garantia de uma remuneração adequada ao investidor em pesquisa e desenvolvimento no domínio farmacêutico pode ser detetada no âmbito do direito da União Europeia, em sede de autorização de introdução dos medicamentos no mercado ${ }^{26}$. Trata-se aqui de uma problemática distinta mas afim do registo de patentes, sendo que nos Estados Unidos elas se encontram conexas através do sistema de patent-linkage.

Para além disso, importa salientar que, nos casos de atraso no procedimento do USPTO, a legislação norte-americana ${ }^{27}$ admite que o proprietário da patente possa, verificados certos requisitos, reclamar o pagamento de royalties em montante "razoável" pelas atividades que configurem uma infração da patente e que tenham ocorrido entre a publicação do pedido e a data da sua emissão ${ }^{28}$. Ponto é que o pedido de patente tenha sido publicado pelo USPTO, as pretensões em causa sejam substancialmente idênticas e o infrator tenha sido por alguma via informado da existência do pedido da patente infringida ${ }^{29}$ - exigência que impede que as empresas de similares e genéricos sejam confrontadas com "patentes-submarino"30.

Estamos diante de uma solução concebida para os casos em que a emissão de uma patente original haja sido protelada no tempo devido a uma falha imputável ao USPTO. A mesma contempla, entre outras coisas, a obrigação de adoção de atos processuais em prazos determinados - sob cominação de extensão da patente - e assegura uma proteção especial no caso de a pendência do pedido vir a exceder os 3 anos, em que cada dia de atraso

26 Neste sentido, Art. 14. $\% 11$ do Regulamento (CE) n. ${ }^{\circ}$ 726/2004 do Parlamento Europeu e do Conselho, de 31 de Março de 2004, que estabelece procedimentos comunitários de autorização e de fiscalização de medicamentos para uso humano e veterinário e que institui uma Agência Europeia de Medicamentos. Aí se dispõe: "Sem prejuízo da legislação relativa à proteção da propriedade industrial e comercial, os medicamentos para uso humano autorizados em conformidade com as disposições do presente regulamento beneficiam de um período de 8 anos de proteção dos dados e de um período de 10 anos de proteção da comercialização; este último será prorrogado até um máximo de 11 anos se, durante os primeiros oito anos daqueles 10, o titular da autorização de introdução no mercado tiver obtido uma autorização para uma ou mais indicações terapêuticas novas que, durante a avaliação científica anterior à sua autorização, sejam consideradas portadoras de um benefício clínico importante relativamente às terapias existentes." (o sublinhado é nosso).

27 Patent Term Guarantee Act, American Inventors Protection Act of 1999 (AIPA), U.S. Code, Title 35, Part II, Chapter 14, § 154.

28 U.S. Code, Title 35, Part II, Chapter 14, § 154, d).

29 PARAD, Dennis J. - Cases Shaping the Understanding of Provisional Patent Rights. Syracuse Journal of Science and Technology Law, 2008. [Consultado em: 18 de Junho de 2018]. Disponível em: http://jost.syr.edu/wp-content/ uploads/cases-shaping-the-understanding-of-provisional-patent-rights.pdf, 1 ss.

30 Sobre o conceito de patentes-submarino, v. BAIR, Stephanie Plamondon - Adjustments, Extensions, Disclaimers, and Continuations: When do Patent Term Adjustments Make Sense?. In Capital University Law Review. Columbus. ISSN 0198-9693. V. 41, N. ${ }^{\circ}$, 2013, 469 ss. 
considerado anormal é compensado pela concessão de um dia de extensão do prazo de validade da patente ${ }^{31}$. Deste modo, a empresa beneficiará pelo menos de 17 anos de proteção patentária (i.e. 20 anos do prazo legal menos os 3 anos de processamento do pedido), o que seria considerado como necessário para recuperar os investimentos feitos para a criação e aprovação do medicamento.

Os ajustamentos positivos do prazo da patente são reduzidos por quaisquer atrasos atribuíveis aos requerentes de patentes. Não há limites para o tempo que pode ser adicionado ao prazo da patente de acordo com esses ajustes. Além disso, esses ajustes são calculados automaticamente pelo USPTO sem pedido do titular da patente. Esta extensão tem uma função corretiva e compensatória, visando restaurar o equilíbrio perdido no processo de ponderação entre inovação e concorrência ${ }^{32}$. Uma patente previamente ajustada de acordo com o § 154 (b) é elegível para uma extensão Hatch-Waxman se os requisitos para tal extensão forem atendidos ${ }^{33}$.

Do ponto de vista jurídico-constitucional, um encurtamento desmesurado do prazo da proteção da patente por falta da devida diligência regulatória configura, desde logo, uma violação do princípio do Estado de direito, no seu subprincípio da legalidade da administração. Assim é porque o artigo $40 .^{\circ}$ da LPIB estabelece um prazo de 20 anos de vigência da patente, a contar da data do depósito.

Um atraso excessivo e irrazoável no exame do pedido e na concessão da patente acaba por redundar, em termos práticos, num encurtamento efetivo e substancial do prazo legalmente estabelecido, violando a lei e conduzindo à frustração dos objetivos do legislador nacional e ao desequilíbrio dos interesses ponderados da inovação e da concorrência ${ }^{34}$. Igualmente violado, neste caso, é o princípio da proporcionalidade em sentido amplo, que também densifica o princípio do Estado de direito, na medida em que o encurtamento da patente configura uma restrição excessiva e irrazoável do direito fundamental de propriedade intelectual do inventor ${ }^{35}$.

Além disso, o atraso excessivo no processamento do pedido de patente também configura uma violação da letra e do espírito do TRIPS. $\mathrm{O}$ artigo $33 .{ }^{\circ}$ desta convenção internacio-

31 U.S. Code, Title 35, Part II, Chapter 14, § 154, b).

32 U.S. Code, Title 35, Part II, Chapter 14, § 154, b).

33 BAIR, Stephanie Plamondon - Adjustments, Extensions, Disclaimers, and Continuations: When do Patent Term Adjustments Make Sense?. In Capital University Law Review. Columbus. ISSN 0198-9693. V. 41, N. ${ }^{\circ}$ 3, $2013,462$.

34 BAIR, Stephanie Plamondon - Adjustments, Extensions, Disclaimers, and Continuations: When do Patent Term Adjustments Make Sense?. In Capital University Law Review. Columbus. ISSN 0198-9693. V. 41, N. ${ }^{\circ}$ 3, 2013,445 ss.

35 CANOTILHO, J.J. Gomes - Direito Constitucional e Teoria da Constituição. 7. ${ }^{\text {a }}$ ed. Coimbra: Almedina, 2003,266 ss. 
nal consagra o mesmo prazo de validade de 20 anos contados a partir do depósito do pedido de patente que serviu de base ao artigo $40 .^{\circ}$ da LPIB.

É certo que parágrafo único do artigo $40 .^{\circ}$ da LPIB dispõe que o prazo de vigência da patente não será inferior a 10 anos, pelo que isso atenua o risco de obliteração do núcleo essencial da proteção patentária. Ainda assim, um atraso excessivo na apreciação do pedido deixará reduzir a proteção patentária em vários anos. Só por si, isso poderia significar lucros cessantes significativos, para não falar na carência de tutela jurídica em que o requerente se pode encontrar durante todo esse período de tempo se não forem adotadas medidas liminares de natureza cautelar.

Ocorre que a mora administrativa na concessão da patente poderá levar ao cenário em que uma vez concedida a patente e garantida a exclusividade, a tecnologia em questão já estará obsoleta, por conta da própria evolução tecnológica presente em cenário concorrêncial. Neste cenário, os consumidores, uma vez concedida a patente, poderão não mais ter interesse naquela tecnologia, razão pela qual estarão frustradas as tentativas do titular de buscar ser ressarcido por investimentos feitos anos atrás.

Além disso, ainda quando concedida a patente, o direito de reparação pelos danos incorridos será sempre limitado a 5 anos, por conta do artigo $225^{\circ}$ da LPIB. Por isso, a ausência de tutela injuntiva durante a pendência do pedido, sistematicamente, acabaria por permitir que o titular, em casos, jamais fosse compensado por todo o período da infração, caso esta se desse entre o depósito e a concessão do pedido de patente:

“Art. 225. Prescreve em 5 (cinco) anos a ação para reparação de dano causado ao direito de propriedade industrial".

Nesta hipótese, haveria um incentivo legal para que a indústria de medicamentos similares e imitações infringisse as invenções, invertendo a lógica do sistema de proteção à propriedade intelectual e à concorrência leal.

Ademais, um dos objetivos fundamentais do TRIPS - de harmonização internacional do regime de propriedade intelectual - será claramente frustrado se os prazos de vigência das patentes variarem de país para país ou, dentro do mesmo país, de empresa para empresa, em função da duração do processamento dos pedidos por parte das autoridades administrativas competentes. Isso introduzirá incerteza jurídica e económica para os inventores potenciais, podendo reduzir significativamente os incentivos para inovar, com consequências para todos quantos necessitam de medicamentos.

Do mesmo modo, o atraso administrativo tem implicações sérias do ponto de vista da justiça, equidade e igualdade, na medida em que empresas colocadas em igualdade de con- 
dições podem acabar por beneficiar de prazos muito diferentes de proteção patentária, por razões que nada têm que ver com o valor social das respetivas tecnologias patenteadas ou com a sua conduta procedimental.

Esse facto pode contribuir, inclusivamente, para distorcer a concorrência, na medida em que introduz um desnivel num campo de jogo que deveria ser nivelado para todos os concorrentes. Mesmo que uma legislação adicional venha ajustar os prazos das patentes com base nos atrasos regulatórios e administrativos ocorridos na emissão de patentes, isso pode sem dúvida ajudar a aliviar tais preocupações, mas não representa necessariamente uma solução completa. Daí que faça sentido avaliar em que medida é que o direito da concorrência pode ser mobilizado pelos tribunais para corrigir as disfunções na aplicação do sistema de patentes.

\section{A estrutura dual de proteção jurídica da inovação}

\section{A. Generalidades}

As normas de propriedade intelectual "institucionalizadas" (i.e. normas de patentes, marcas, direitos de autor) criam um quadro abrangente de ponderações que proporciona um sistema de equilíbrio interno entre os interesses envolvidos, de inovação e concorrência. Inevitavelmente, este sistema é imperfeito e incompleto. $\mathrm{O}$ atraso administrativo excessivo na concessão de patentes (para não falar na lentidão dos tribunais) é apenas uma das suas deficiências.

Por isso, ele exige complementos e correções. Nas linhas subsequentes iremos ver como a doutrina e a jurisprudência comparadas mobilizam os conceitos de concorrência desleal, apropriação indevida e enriquecimento sem causa para fundamentar a tutela injuntiva e restitutiva. Desse modo, cria-se uma estrutura dual de proteção jurídica (dual path doctrine) $)^{36}$.

Por um lado, apela-se ao direito da propriedade intelectual e ao sistema de patentes tal como este se encontra institucionalizado. Por outro lado, mesmo que não haja lugar, formalmente, a qualquer violação do sistema de normas da propriedade intelectual, pode justificar-se a mobilização alternativa de princípios, doutrinas e meios de tutela situados para além deste domínio normativo quando isso se afigure necessário para corrigir disfunções do sistema de propriedade intelectual ${ }^{37}$.

36 A expressão é usada por DEUTCH, Miguel - Unfair Competition And The "Misappropriation Doctrine" - A Renewed Analysis. In Saint Louis University Law Journal. St. Louis. ISSN 0036-3030. V. 48, 524.

37 Estes aspetos são sublinhados por DEUTCH, Miguel - Unfair Competition And The "Misappropriation Doctrine" - A Renewed Analysis. In Saint Louis University Law Journal. St. Louis. ISSN 0036-3030. V. 48, 2004, 503 Ss. 


\section{B. Concorrência desleal}

Ao longo das décadas tem havido muitos casos em que a conduta abusiva dos titulares das patentes faz sentir o seu impacto muito para além do domínio da propriedade intelectual (lato sensu), com especial relevo para o direito da concorrência ${ }^{38}$. Há muito que a doutrina e a jurisprudência assinalam a relação de proximidade que se estabelece entre o direito da propriedade intelectual e industrial e o direito da concorrência (antitrust law) ${ }^{39}$.

Essa proximidade é visível em domínios como os contratos exclusivos de licenciamento ou outros contratos envolvendo patentes ou ainda com os acordos de pagamento para atraso da entrada no mercado ou os acordos celebrados entre empresas em processos por infração de patentes ${ }^{40}$. O artigo $2 .{ }^{\circ} / 1 / \mathrm{V}$ da LPIB dispõe que a proteção dos direitos relativos à propriedade industrial, considerado o seu interesse social e o desenvolvimento tecnológico e económico do País, efetua-se mediante a repressão à concorrência desleal.

A aplicação do direito da propriedade intelectual tem sido complementada e corrigida por via dos princípios de controlo extraídos do direito da concorrência, nos casos em que o simples jogo das normas de proteção da propriedade intelectual em vigor conduz a resultados incoerentes marcados pela disfunção sistémica (systemwidrigkeit) ou, o que é o mesmo, contrários à justiça do sistema (systemgerechtigkeit), tendo por quadro de referência não necessariamente o sistema jurídico globalmente considerado, como deve ser, mas mesmo apenas os objetivos do próprio sistema de patentes ${ }^{41}$.

Inversamente, nada exclui à partida a possibilidade de algumas condutas das empresas de genéricos e similares poderem vir a ser qualificadas como anti-concorrenciais, infringindo os princípios de concorrência leal e não falseada. Neste âmbito, impõe-se a mobilização, pelos tribunais, da chamada "rule of reason", largamente conformada pelas ideias de ponderação de bens, harmonização, otimização, máxima efetividade, justo equilíbrio, razoabilidade e proporcionalidade em sentido amplo, especialmente naqueles casos em que a conduta unilateral das empresas possa ser interpretada como desleal e de má-fé t2 $^{2}$.

Assim será, por sinal, nos casos em que um pedido de patente formulado por uma empresa de referência se encontre pendente num procedimento administrativo de aprecia-

38 BALTO, David A.; WOLMAN, Andrew M. - Intellectual Property and Antitrust: General Principles. In IDEA: The Journal of Law and Technology. Washington. ISSN 0019-1272. V. 43, 2003, 395 ss.

39 HOVENKAMP, Herbert - Antitrust and the Patent System: A Reexamination. In Ohio State Law Journal. Columbus. ISSN 0048-1572. V. 76, N. ${ }^{\circ} 3,2015,476$ ss.

40 HEMPHILL, C. Scott - Paying For Delay: Pharmaceutical Patent Settlement As A Regulatory Design Problem. In New York University Law Review. New York. ISSN 0028-7881. V. 81, N. ${ }^{\circ}$ 5, 2006, 1553 ss.

41 Veja-se, em termos gerais, DIETRICH, Peter - Systemgerechtigkeit und Kohärenz: Legislative Einheit und Vielheit durch Verfassungs- und Unionsrecht. Berlin: Duncker \& Humblot, 2014, 7 ss.

42 HOVENKAMP, Herbert - The Rule of Reason and the Scope of the Patent. In San Diego Law Review. San Diego. ISSN 0036-4037. V. 52, 2015, 515 ss. 
ção cuja duração haja ultrapassado os limites do aceitável e razoável, do ponto de vista dos princípios da legalidade da administração, dos direitos dos particulares e, mais especificamente, do direito fundamental a uma boa administração.

Um dos objetivos fundamentais do direito da concorrência consiste em assegurar uma concorrência livre e justa no seio de uma economia social de mercado. Pretende-se, desde logo, dar resposta ao chamado free rider problem, que se manifesta na tentativa empreendida por algumas empresas no sentido de se prevalecerem dos investimentos que outras tenham realizado, sem assumir a sua quota parte dos custos, de acordo com os princípios gerais e as máximas de justiça comutativa (Ubi commoda, ibi incommoda; "tudo o que o homem semear, isso também ceifará"). Este princípio implica, desde logo, a rejeição de práticas de concorrência desleal que permitam arrecadar os lucros do capital que outros investiram.

O mesmo tem ampla radicação no direito empresarial e da concorrência, considerando-se que é indispensável à garantia do bom funcionamento do mercado. O artigo 39. do TRIPS - respeitante à proteção da informação dos ensaios pré-clínicos e clínicos das empresas farmacêuticas submeteram às autoridades regulatórias estatais - consagra o princípio da proibição da concorrência desleal, remetendo para o artigo $10 .^{\circ}$ bis da Convenção de Paris (1967) ${ }^{43}$.

Mais do que um apelo vago e indefinido ao "fair play", à boa-fé, à "lealdade", à "honestidade" ou simplesmente à máxima "gentlemen play by the rules", o âmbito normativo da proibição da concorrência desleal, concebido em termos deliberadamente abertos, e não taxativos, de maneira a abranger uma constelação de condutas concretas, como sejam, nomeadamente, abuso de posição dominante, exploração de uma especial vulnerabilidade de um concorrente, infração de marca ou patente, diluição de marca, suborno numa licitação, falsa representação ou descrição de empresa, bem ou serviço ou apropriação indevida de informações e conhecimentos, que sejam suscetíveis de causar danos severos a um concorrente $^{44}$.

\section{Apropriação indevida}

De acordo com a doutrina da apropriação indevida (misapropriation doctrine) ${ }^{45}$, o conceito de concorrência desleal adquire relevância nos casos em que mesmo supostamente não havendo lugar à proteção patentária - nomeadamente quando isso decorra de atraso admi-

43 NORTON, Patricia V. - The Effect of Article 1obis of the Paris Convention on American Unfair Competition Law. In Fordham Law Review. New York. ISSN 0015-704X. V. 68, N. ${ }^{\circ}$ 1, 1999, 225 ss.

44 DEUTCH, Miguel - Unfair Competition And The "Misappropriation Doctrine" - A Renewed Analysis. In Saint Louis University Law Journal. St. Louis. ISSN 0036-3030. V. 48, 2004, 503 ss.

45 SELL, Edward - The Doctrine of Misappropriation in Unfair Competition. In Vanderbilt Law Review. Nashville. ISSN 0042-2533. V. 11, 1958, 483, 496-499. 
nistrativo e não seja imputável à empresa de referência - um concorrente decide copiar o medicamento de referência para introduzir um medicamento similar no mercado a preço mais baixo ${ }^{46}$. A apropriação indevida ocorre quando sejam utilizados elementos essenciais da informação e do conhecimento objeto de proteção patentária, atual ou potencial, com o objetivo de criar produtos substancialmente similares, mesmo que isso não se traduza numa replicação completa ${ }^{47}$.

Nestes casos, o direito confronta-se com o interesse da empresa inovadora que investiu recursos e dinheiro para proteger o fruto do seu trabalho, enquanto o concorrente atua como um "free rider", procurando desfrutar o benefício desse investimento sem qualquer consideração. A empresa inovadora baseará a sua pretensão de proteção jurídica recorrendo a conceitos básicos subjacentes ao direito de propriedade, ou seja, "a teoria do trabalho-propriedade".

De acordo com esta teoria, o direito de propriedade não pode deixar de considerar o valor-trabalho acrescentado pelo respetivo titular, sendo certo que o investimento em pesquisa e desenvolvimento se repercute no valor dos bens. Com efeito, a teoria da apropriação indevida leva em conta duas variáveis fundamentais: o investimento feito para obter o ativo tangível ou intangível, por um lado, e, por outro lado, a tentativa de outrem de recolher benefícios desse investimento para o que em nada contribuiu.

Acresce que existe um interesse público constitucional na proteção dos investimentos realizados e dos inventores individuais e coletivos, na medida em que são eles que propiciam "o desenvolvimento tecnológico e económico do País", que, nos termos da Constituição brasileira, constitui o fundamento para a proteção da propriedade intelectual. Este interesse leva a que se procure evitar que os não inovadores enriqueçam à custa do esforço dos inovadores e que, por essa via, se desincentive a pesquisa científica e o desenvolvimento tecnológico que deve estar na base do progresso económico da comunidade política. Conclui-se, portanto, que também considerações de política pública corroboram a aplicação da doutrina da apropriação indevida.

Mesmo que se reconheça a existência de um interesse social razoável em evitar uma sobre-utilização da doutrina da apropriação indevida por vir a ser nociva para os interesses dos concorrentes e dos consumidores, sempre que se terá de conceder que a generalização da prática de apropriação indevida dos ativos tangíveis e intangíveis de outrem - apenas

46 Discutindo precisamente esta situação, veja-se DEUTCH, Miguel - Unfair Competition And The "Misappropriation Doctrine" - A Renewed Analysis. In Saint Louis University Law Journal. St. Louis. ISSN 0036-3030. V. 48, 2004, 503 ss., 515.

47 DEUTCH, Miguel - Unfair Competition And The "Misappropriation Doctrine" - A Renewed Analysis. In Saint Louis University Law Journal. St. Louis. ISSN 0036-3030. V. 48, 2004, 523 ss. 
para os copiar ou vender a um preço mais baixo num mercado secundário de réplicas ou similares - não deixaria de representar um forte desincentivo ao investimento e à inovação, para além de representar um locupletamento à custa de outrem.

É o produto original que leva ao enriquecimento do concorrente que o imitou. Este não tem que suportar os custos da pesquisa, dos ensaios pré-clínicos e clínicos e da álea do seu desfecho incerto. O proprietário do medicamento de referência é lesado como consequência da venda do produto similar, na medida em que há clientes que teriam comprado o original, mas que ficam agora satisfeitos com a imitação.

Ora, a liberdade de concorrência não equivale à liberdade de apropriação indevida nem justifica a concorrência desleal. Seria inconcebível alguém argumentar que a liberdade de concorrência por si só justifica a apropriação indevida da propriedade intelectual ${ }^{48}$. Como sustenta o eminente jurista e juiz constitucional israelita Aaron Barak, "quanto mais importante o trabalho, mais inovadora, mais singular e mais significativa a sua contribuição, maior será a tendência de considerar uma imitação ou uma cópia dela como concorrência desleal" 49 .

Admite-se que razões de segurança jurídica, certeza, previsibilidade e proteção da confiança possam levar alguns autores a circunscrever a aplicação das doutrinas da concorrência desleal e da apropriação indevida, na melhor das hipóteses, a situações excecionais de injustiça manifesta e clamorosa. No entanto, não é claro que razões de justiça possam ser sistematicamente preteridas em favor da certeza do direito.

Em todo o caso, é inquestionável que na situação em apreço se verificam as circunstâncias adequadas à mobilização aos princípios gerais de proibição da concorrência desleal e da apropriação indevida. Uma espera excessiva para obtenção de uma decisão definitiva sobre um pedido de patente implica uma redução substancial de proteção patentária e do prazo legalmente prescrito para a recuperação do investimento da empresa inovadora, ainda que venha a ser considerado futuramente o prazo do artigo $40 .^{\circ}$, parágrafo único. Por esse motivo, os tribunais têm o dever de conceder uma proteção reforçada à empresa inovadora contra o risco de apropriação indevida de propriedade de intangíveis como a informação e o conhecimento, precisamente porque a mesma não pode ver decidida a sua proteção patentária em tempo útil.

Assim é, porque é evidente que o atraso altera completamente a ponderação de interesses subjacente ao sistema de patentes, traduzindo-se num defeito de proteção jurídica causado pela falta da devida diligência regulatória, que é suscetível de privar a empresa inovadora de

48 DEUTCH, Miguel - Unfair Competition And The "Misappropriation Doctrine" - A Renewed Analysis. In Saint Louis University Law Journal. St. Louis. ISSN 0036-3030. V. 48, 2004.

49 Na decisão do Supremo Tribunal de Israel no caso A.L.A. 5768/94, ASHIR, 52(4) P.D. 289, 432, 449. 
parte substancial dos direitos que em condições normais poderia já ter visto reconhecidos, a saber, de prioridade e exclusividade temporária na exploração comercial dos seus medicamentos, com um forte impacto nos rendimentos esperados.

\section{Enriquecimento sem causa}

O conceito de concorrência desleal remete, inevitavelmente, para a lógica subjacente à figura do enriquecimento sem causa. A mesma proscreve o locupletamento injusto à custa de outrem, destituído de causa justificativa, e prescreve a restituição dos lucros indevidamente obtidos, o que poderia ir além de um mero royalty razoável por infração da patente entre o depósito do pedido e a decisão de concessão.

Ponto é que o enriquecimento não seja considerado justificável à luz da justiça do sistema jurídico que naturalmente deve estruturar as relações entre os particulares. A interpretação e aplicação desta figura aponta para uma leitura substantiva e material do ordenamento jurídico - não estritamente positivista, legalista e formalista - em que os princípios de justiça e equidade adquirem densidade conformadora normativa, de acordo com uma orientação de primazia da substância sobre a forma e atenção à substância económica das transações.

Radicada no direito romano e com uma profícua trajetória na tradição do common law, a proibição do enriquecimento sem causa é um princípio geral do direito, com ampla relevância no direito privado, seja ele civil, comercial ou da concorrência ${ }^{50}$. Ela opera de modo subsidiário, sempre que a lei não faculte ao empobrecido um outro meio de ser indemnizado ou restituído. A mesma aplica-se a situações em que um benefício seja obtido sem causa jurídica e económica justificativa, incluindo casos em que, mesmo não havendo uma violação de lei, ato ou contrato, o benefício obtido é manifestamente injusto e contrário às finalidades do sistema jurídico. Em todo o caso, essa avaliação deve ser baseada em princípios de justiça e levada a cabo de maneira flexivel e circunstancial ${ }^{51}$.

A doutrina tem chamado à atenção de que esta figura conserva ainda hoje incontestáveis virtualidades na litigância no âmbito da regulação, da concorrência e da propriedade intelectual, podendo aí funcionar como um importante complemento e corretivo do ponto de vista das causas e dos meios de ação, garantindo um resultado justo e equitativo quando as demais normas em vigor se revelam insuficientes. Isto, sem prejuízo de se entender que este instituto não é meramente residual, antes integrando plenamente o sistema de valores, princípios e regras da ordem jurídica. A energia normativa do enriquecimento sem

50 Artigos $884 .^{\circ}$ a $886 .^{\circ}$ do Código Civil Brasileiro; artigos $473 .^{\circ}$ a 482 do Código Civil Português.

51 Isto mesmo é sublinhado por DEUTCH, Miguel - Unfair Competition And The "Misappropriation Doctrine" - A Renewed Analysis. In Saint Louis University Law Journal. St. Louis. ISSN 0036-3030. V. 48, 2004, 517 ss. 
causa pode ser canalizada com virtualidades inegáveis para o domínio da concorrência desleal e da apropriação indevida ${ }^{52}$.

O artigo $210 .^{\circ}$ da LPIB, relevante na sua conexão com o artigo $44 .^{\circ}$ da LPIB, incorpora a lógica da restituição por enriquecimento sem causa quando prevê, a título de indemnização de lucros cessantes, a devolução dos benefícios que foram auferidos pelo autor da violação do direito se esse valor for superior ao dos benefícios que o prejudicado teria auferido se a violação não tivesse ocorrido.

Ainda assim, como se verá, há casos em que a tutela injuntiva prevalece sobre a lógica da restituição a posteriori, observadas as particularidades da dificuldade ou quase impossibilidade de restituição, em tempo útil, dos prejuízos sofridos, de difícil cálculo, além da difícil retirada de medicamento do mercado, uma vez inserido neste.

A relevância do enriquecimento sem causa é clara nos casos de infração de patente, havendo múltiplos exemplos da sua aplicação neste âmbito ${ }^{53}$. No entanto, o recurso ao enriquecimento sem causa não pressupõe necessariamente a violação de lei, o incumprimento de obrigação contratual ou a infração de uma patente. Em causa pode estar simplesmente a proteção dos "frutos do trabalho" de um particular diante dos riscos de uma apropriação indevida por empresas concorrentes no mercado ${ }^{54}$. $O$ fundamento para a imposição de uma proibição de enriquecimento sem causa em relação à apropriação indevida de produtos intelectuais (i.e. informação; conhecimento) é a prevenção da concorrência desleal.

Por esse motivo, este instituto faz todo o sentido num caso em que uma empresa, de forma consciente e intencional, pretende obter lucros através da colocação no mercado de um medicamento similar a um medicamento de referência, tirando partido de um atraso anormal do processo administrativo de apreciação do pedido de concessão de uma patente. Essa empresa não teve que suportar os custos da investigação inovadora nem que se sujeitar a prolongados e incertos ensaios pré-clínicos e clínicos, bastando apropriar-se de conhecimento inovador pré-existente e colher daí apreciáveis benefícios à custa dos prejuízos de outrem.

O enriquecimento assim obtido dificilmente pode considerar-se suportado por uma causa justificativa insuficiente, do ponto de vista jurídico e económico, afigurando-se manifestamente injusto, quando a empresa que suportou os custos da pesquisa e do desenvolvimento do medicamento de referência aguarda por uma decisão final por um período

52 DEUTCH, Miguel - Unfair Competition And The "Misappropriation Doctrine" - A Renewed Analysis. In Saint Louis University Law Journal. St. Louis. ISSN 0036-3030. V. 48, 2004, 517 ss. e 520 ss.

$53 \mathrm{ROACH}$, George P. - How Restitution and Unjust Enrichment Can Improve Your Corporate Claim. In The Review of Litigation. Austin. ISSN 0734-4015. V. 26, 2007, p. 265-400, 265 ss., 300.

54 DEUTCH, Miguel - Unfair Competition And The "Misappropriation Doctrine" - A Renewed Analysis. In Saint Louis University Law Journal. St. Louis. ISSN 0036-3030. V. 48, 2004, 503 ss. 
de tempo que ultrapasse os padrões aceitáveis de diligência regulatória adequada (regulatory due-dilligence).

\section{Propriedade intelectual, concorrência desleal e tutela liminar}

\section{A. Generalidades}

O princípio do Estado de direito tem como corolário densificador o direito à proteção jurisdicional efetiva. Este direito reveste-se de inteira pertinência na matéria em apreço. Dos tribunais espera-se que garantam a integridade, racionalidade e consistência do sistema de patentes. Este sistema preserva os incentivos à inovação, proporcionando uma medida significativa de certeza para potenciais inovadores. Ele também pretende dar resposta a preocupações de legalidade, justiça, equidade e igualdade, porque promove a consistência nos prazos da patente, evitando que os mesmos difiram significativamente entre si por razões totalmente alheias e relapsas ao controlo das empresas requerentes das patentes.

\section{B. Tutela cautelar do titular da patente}

De um modo geral, entende-se que o titular da patente pode recorrer a injunções preliminares de natureza cautelar para se proteger de uma violação dos seus direitos de propriedade intelectual atual ou iminente ${ }^{55}$. Nesta mesma linha a LPIB estabelece:

"Art. 42. A patente confere ao seu titular o direito de impedir terceiro, sem o seu consentimento, de produzir, usar, colocar à venda, vender ou importar com estes propósitos:

I - produto objeto de patente;

II - processo ou produto obtido diretamente por processo patenteado.

$\S 1 .^{\circ}$ Ao titular da patente é assegurado ainda o direito de impedir que terceiros contribuam para que outros pratiquem os atos referidos neste artigo".

A existência de meios processuais de tutela preventiva de natureza urgente e cautelar afigura-se indispensável para impedir a colocação no mercado de medicamentos similares que representem uma infração de patente.

55 Sobre este meio processual no direito de patentes alemão, veja-se FEI, Charleen - Justice Delayed Is Justice Denied? The Principle of Bifurcation in The German Patent Litigation System. In Wake Forest Journal of Business and Intellectual Property Law. Winston-Salem. ISSN 2164-6945. V. 14, N. ${ }^{4}$, 2014, 619 ss., esp. 631 ss. 


\section{Tutela cautelar entre o depósito e a concessão}

As considerações anteriormente desenvolvidas sustentam o entendimento de que não se pode afastar a possibilidade de providências injuntivas de natureza cautelar mesmo antes da concessão da patente, especialmente nos casos em que se verifica um atraso manifestamente inaceitável e desproporcional do processo de exame do pedido de patente.

A força normativa das doutrinas da concorrência desleal e da apropriação indevida permite viabilizar, com o apoio da doutrina e da jurisprudência comparadas, o direito a uma tutela jurisdicional urgente, de natureza cautelar, por via de uma injunção (writ) para a prevenção de condutas atuais ou iminentes julgadas potencialmente lesivas e contrárias aos princípios fundamentais do ordenamento jurídico, suscetíveis de causar danos irreparáveis ou de muito difícil reparação ${ }^{56}$.

\section{Critérios de ponderação avançados pela doutrina}

A doutrina da apropriação indevida, com ampla radicação no direito da concorrência e na proibição da concorrência desleal, confere densidade e pertinência a esta disposição, assumindo grande relevância no caso concreto. A mesma é tanto mais relevante quanto é certo que não se prevê uma prorrogação do prazo da patente para compensar, com maior equivalência entre a mora administrativa e o prazo suplementar concedido, os atrasos regulatórios, como sucede nos Estados Unidos. Naturalmente que uma tal providência tem que obedecer a uma cuidadosa ponderação de vários critérios. Para decidir sobre este meio de tutela importa atender a variáveis como:

a) o tempo de espera do processo de apreciação da patente;

b) o custo de investimento em pesquisa, ensaios pré-clínicos e clínicos e no registo e defesa da patente por parte da empresa inovadora;

c) a poupança de investimento em pesquisa, ensaios pré-clínicos e clínicos e no registo e defesa da patente por parte da empresa imitadora;

d) os lucros potenciais que a empresa imitadora pode obter à custa da empresa inovadora;

e) a consciência de apropriação indevida do produto de referência por parte da empresa imitadora;

f) a intenção concorrencial com que são levadas a cabo a cópia e a introdução do medicamento similar no mercado por parte da empresa imitadora;

56 Neste sentido, DEUTCH, Miguel - Unfair Competition And The "Misappropriation Doctrine" - A Renewed Analysis. In Saint Louis University Law Journal. St. Louis. ISSN 0036-3030. V. 48, 2004, 503 ss., 552 ss. 
g) a plausibilidade da expectativa de obtenção de um direito exclusivo temporário por parte da empresa inovadora;

h) o impacto da colocação dos similares no mercado no retorno do investimento esperado pela empresa inovadora ${ }^{57}$.

Estes critérios de ponderação, tal como delineados pela doutrina e jurisprudência comparadas, oferecem ao operador jurídico uma paleta cromática de excelente qualidade jurídico-dogmática. Não bastando aqui uma referência meramente abstrata e impressionista, impõe-se fixar em tela algumas sugestões em traços largos dotadas de intensidade e consistência suficientes para que se aprecie as virtualidades da sua aplicação ao caso concreto. Esta tarefa será operacionalizada tendo em conta as características próprias do ordenamento jurídico brasileiro.

\section{E. A tutela liminar à luz do artigo $209 .^{\circ}$ da LPIB}

A possibilidade de uma tutela liminar de natureza cautelar encontra-se expressamente prevista na LPIB que remete para vias de proteção localizadas para além desse mesmo instrumento legal. Na verdade, deve considerar-se que a tutela liminar decorre diretamente do princípio do Estado de direito e do direito a uma tutela jurisdicional efetiva e sem lacunas.

Na verdade, uma parte significativa da doutrina sustenta que a possibilidade de decretar providências liminares de natureza cautelar, com uma função conservatória do objeto de proteção ou antecipatória da proteção pretendida, constitui uma prerrogativa inerente ao exercício da própria função jurisdicional, não carecendo sequer de um fundamento normativo expresso. Em causa está, tão-somente, o objetivo de assegurar o efeito útil dos meios jurisdicionais de proteção.

Em todo o caso, o artigo 209. ${ }^{\circ}$ da LPIB prevê expressamente essa possibilidade quando aborda conjuntamente a problemática da proteção da propriedade industrial e a prevenção e repressão de atos de concorrência desleal. Vejamos o preceito relevante;

"Art. 209. Fica ressalvado ao prejudicado o direito de haver perdas e danos em ressarcimento de prejuízos causados por atos de violação de direitos de propriedade industrial e atos de concorrência desleal não previstos nesta Lei, tendentes a prejudicar a reputação ou os negócios alheios, a criar confusão entre estabelecimentos comerciais, industriais ou

57 Estes critérios são identificados por DEUTCH, Miguel - Unfair Competition And The "Misappropriation Doctrine" - A Renewed Analysis. In Saint Louis University Law Journal. St. Louis. ISSN 0036-3030. V. 48, 2004, 503 ss., 552 ss. 
prestadores de serviço, ou entre os produtos e serviços postos no comércio. (o sublinhado énosso)

$\S 1 .^{\circ}$ Poderá o juiz, nos autos da própria ação, para evitar dano irreparável ou de difícil reparação, determinar liminarmente a sustação da violação ou de ato que a enseje, antes da citação do réu, mediante, caso julgue necessário, caução em dinheiro ou garantia fidejussória".

O teor literal desta disposição reveste-se de incontornável relevância para o caso em apreço, na medida em que prevê expressamente, não apenas a tutela compensatória de perdas e danos causados por violação da propriedade intelectual e da concorrência desleal, mas também a tutela liminar de urgência para a sustação de qualquer ato que a enseje e de que possa resultar dano irreparável ou de difícil reparação.

Por outras palavras, uma exegese atenta do texto do artigo $209 .^{\circ}$ da LPIB revela que, no quadro do ordenamento jurídico brasileiro, não faz sentido, em rigor, falar na existência de uma estrutura dual de proteção jurídica, assente na bifurcação entre tutela da propriedade intelectual, por um lado, e proibição da concorrência desleal, por outro.

Diferentemente, os vários afluentes de proteção jurídica, alicerçados nos conceitos jurídicos de propriedade intelectual (lato sensu), proteção patentária, direitos exclusivos temporários, proibição da concorrência desleal, apropriação indevida e enriquecimento sem causa se encontram no estuário do artigo 209. ${ }^{\circ}$ da LPIB, onde se manifestam como uma só realidade digna e carecida de tutela ex ante - a título liminar e cautelar - e ex post - a titulo de reparação de perdas e danos. Este aspeto reforça a argumentação expendida no presente texto, na medida em que muitas das ilações doutrinais e jurisprudenciais que consideramos relevantes se podem deduzir, com toda a propriedade substantiva e lógico-formal, do artigo 209. ${ }^{\circ}$ da LPIB, com especial relevo para o respetivo parágrafo único.

Os contributos que a doutrina especializada tem dado para a densificação dos conceitos de concorrência desleal, apropriação indevida e enriquecimento sem causa podem ser mobilizados para esclarecer os pontos mais dubitativos da respetiva aplicação pelo poder judicial. Eles mostram que mesmo nos casos em que isso não esteja expressamente previsto na lei, a tutela liminar durante o prazo de pendência do pedido da patente é uma via inteiramente plausível de proteção jurídica, quando razões de natureza concorrencial militem nesse sentido.

Esses contributos doutrinais devem ser interpretados no sentido de reforçar a necessidade de garantir uma tutela jurisdicional efetiva e sem lacunas ${ }^{58}$, prevenindo a imposição 
de danos irreparáveis às empresas inovadoras, por parte das empresas imitadoras, por ocasião da demora excessiva no processo de apreciação dos pedidos de patentes.

\section{Conclusão}

O prolongamento excessivo do processo administrativo de apreciação do pedido de registo de patente diminui substancialmente a vida útil da patente quando a mesma venha a ser concedida, e dá origem a incerteza e insuficiência de proteção antes da concessão da patente, constituindo um forte desincentivo à inovação e frustrando os objetivos prosseguidos pela legislação nacional de propriedade industrial e pelo TRIPS.

O atraso irrazoável e desproporcional na apreciação de pedidos de registos de patentes introduz incerteza e insegurança jurídica no sistema de proteção patentária, podendo ter consequências económicas deletérias não apenas para os requerentes das patentes, mas igualmente para a comunidade técnica e científica globalmente considerada.

Se os inventores só pudessem obter compensação pelas infrações verificadas depois da concessão da patente, os mesmos ficariam numa posição de especial vulnerabilidade económica no período entre o depósito do pedido de patente e a decisão definitiva de atribuição, em termos que em larga medida escapariam ao seu controlo.

O direito brasileiro, à semelhança do que sucede com os seus congéneres, garante uma medida de proteção ao inventor entre a publicação do pedido e a concessão da patente.

Ao titular da patente é assegurado o direito de obter indemnização pela exploração indevida de seu objeto, inclusive em relação à exploração ocorrida entre a data da publicação do pedido e a da concessão da patente.

A tutela compensatória não é suficiente para prevenir os danos causados, razão pela qual a tutela injuntiva é por vezes necessária.

Não se deve afastar a possibilidade de providências injuntivas de natureza cautelar mesmo antes da concessão da patente nos casos em que se verifica um atraso inaceitável e desproporcional do processo administrativo de exame do pedido de patente.

A tutela liminar decorre diretamente do princípio do Estado de direito e do direito a uma tutela jurisdicional efetiva e sem lacunas.

A possibilidade de decretar providências liminares de natureza cautelar, com uma função conservatória do objeto de proteção ou antecipatória da proteção pretendida, constitui uma prerrogativa inerente ao exercício da própria função jurisdicional, não carecendo sequer de um fundamento normativo expresso.

Ainda assim, o artigo 209. ${ }^{\circ}$ da LPIB prevê expressamente essa possibilidade quando aborda conjuntamente a problemática da proteção da propriedade industrial e a prevenção 
e repressão de atos de concorrência desleal. O teor literal desta disposição prevê expressamente, não apenas a tutela compensatória de perdas e danos causados por violação da propriedade intelectual e da concorrência desleal, mas também a tutela liminar de urgência para a sustação de qualquer ato que a enseje e de que possa resultar dano irreparável ou de difícil reparação.

\section{Bibliografia}

ALI, Feroz - Technical Speech: Patents, Expert Knowledge, and the First Amendment. In Minnesota Journal of Law, Science \& Technology. Minneapolis. ISSN 1552-9541. V. 17, N. ${ }^{\circ} 1,2016$, p. 277-345.

BAIR, Stephanie Plamondon - Adjustments, Extensions, Disclaimers, and Continuations: When do Patent Term Adjustments Make Sense?. In Capital University Law Review. Columbus. ISSN 0198-9693. V. 41, N. ${ }^{\circ} 3,2013$, p. 445-511.

The Psychology of Patent Protection. In Connecticut Law Review. Hartford. ISSN 0010-6151. V. 48, N. 2, 2015, p. 299-353.

BALTO, David A.; WOLMAN, Andrew M. - Intellectual Property and Antitrust: General Principles. In IDEA: The Journal of Law and Technology. Washington. ISSN 0019-1272. V. 43, 2003, p. 395-474.

CAMPBELL, Randy L. - Global Patent Law Harmonization: Benefits and Implementation. In Indiana International \& Comparative Law Review. Indianapolis. ISSN 1061-4982. V. 13, N. ${ }^{\circ}$ 2, 2003, p. 605-638.

CANOTILHO, J.J. Gomes - Direito Constitucional e Teoria da Constituição. 7. ed. Coimbra: Almedina, 2003.

CARVALHO, Nuno Pires de - The TRIPS Regime of Patent Rights. $2 .^{\mathrm{a}}$ ed. The Hague: Kluwer Law International, 2005.

COLLEEN, Kelly - The Balance Between Innovation and Competition: The Hatch-Waxman Act, the 2003 Amendments, and Beyond. In Food and Drug Law Journal. Washington. ISSN 1064-590X. V. 66, N. ${ }^{\circ} 3$, 2011, p. 417-478.

DEUTCH, Miguel - Unfair Competition And The "Misappropriation Doctrine" - A Renewed Analysis. In Saint Louis University Law Journal. St. Louis. ISSN 0036-3030. V. 48, 2004, p. 503-545.

DIETRICH, Peter - Systemgerechtigkeit und Kohärenz: Legislative Einheit und Vielheit durch Verfassungsund Unionsrecht. Berlin: Duncker \& Humblot, 2014.

FEI, Charleen - Justice Delayed Is Justice Denied? The Principle of Bifurcation in The German Patent Litigation System. In Wake Forest Journal of Business and Intellectual Property Law. Winston-Salem. ISSN 2164-6945. V. 14, N. ${ }^{\circ}$ 4, 2014, p. 619-670.

GAUDRY, Kate S. - Uncharted Territories of the Patent-Restoration Due-Diligence Challenge. In Food and Drug Law Journal. Washington. ISSN 1064-590X. V. 66, N. ${ }^{\circ}$ 1, 2011, p. 121-138.

HEMPHILL, C. Scott - Paying For Delay: Pharmaceutical Patent Settlement As A Regulatory Design Problem. In New York University Law Review. New York. ISSN 0028-7881. V. 81, N. ${ }^{0}$ 5, 2006, p. 1553-1623. HOVENKAMP, Herbert - Antitrust and the Patent System: A Reexamination. In Ohio State Law Journal. Columbus. ISSN 0048-1572. V. 76, N. ${ }^{\circ} 3,2015$, p. 467-564.

HOVENKAMP, Herbert - The Rule of Reason and the Scope of the Patent. In San Diego Law Review. San Diego. ISSN 0036-4037. V. 52, 2015, p. 515-554.

MACHADO, Jónatas; RAPOSO, Vera - Direito à Saúde e Qualidade dos Medicamentos: Proteção dos Dados de Ensaios Clínicos Numa Perspetiva de Direito Brasileiro, Comparado e Internacional. Coimbra: Almedina, 2010. 
MOTTA, Massimo - Competition Policy: theory and practice. Cambridge, New York: Cambridge University Press, 2004.

MURRAY, Kali N. - Constitutional Patent Law: Principles and Institutions. In Nebraska Law Review. Lincoln. ISSN 0047-9209. V. 93, N. ${ }^{\circ} 4$, 2015, p. 901-949.

NAQI, Sharick - Comment on Provisional Patent Rights. In Northwestern Journal of Technology and Intellectual Property. Chicago. ISSN 1549-8271. V. 10, N. ${ }^{\circ}$ 7, 2012, p. 595-606.

NORTON, Patricia V. - The Effect of Article 1obis of the Paris Convention on American Unfair Competition Law. In Fordham Law Review. New York. ISSN 0015-704X. V. 68, N. ${ }^{0}$ 1, 1999, p. 225-255.

PARAD, Dennis J. - Cases Shaping the Understanding of Provisional Patent Rights. Syracuse Journal of Science and Technology Law, 2008. [Consultado em: 18 de Junho de 2018]. Disponível em: http://jost.syr. edu/wp-content/uploads/cases-shaping-the-understanding-of-provisional-patent-rights.pdf.

QUILLEN JR., Cecil D.; WEBSTER, Ogden H. - Continuing Patent Applications and the U.S. Patent and Trademark Office-Updated". In The Federal Circuit Bar Journal. Washington. ISSN 1055-8195. V. 15, N. ${ }^{\circ}$ 4, 2006, p. 635-677.

ROACH, George P. - How Restitution and Unjust Enrichment Can Improve Your Corporate Claim. In The Review of Litigation. Austin. ISSN 0734-4015. V. 26, 2007, p. 265-400.

ROSENBAUM, Sara - The Globalization of Health Care. In Tulsa Law Review. Tulsa. ISSN 1538-9979. V. 50, N. ${ }^{\circ}$ 2, 2015, p. 607-612.

SELL, Edward - The Doctrine of Misappropriation in Unfair Competition. In Vanderbilt Law Review. Nashville. ISSN 0042-2533. V. 11, 1958, p. 483-499.

SINGER, Joseph William - Property as the Law of Democracy. In Duke Law Journal. Durham. ISSN 1939-9111. V. 63, N. $^{\circ} 6,2014$, p. 1287-1335.

TORRANCE, Andrew W.; HIPPEL, Eric von - The Right to Innovate. In Michigan State Law Review. East Lansing. ISSN 0026-2234. N. ${ }^{\circ}$ 793, 2015, p. 793-829.

TU, Sean - Understanding The Backlog Problems Associated With Requests For Continued Examination Practice. In Duke Law \& Technology Review. Durham. ISSN 2328-9600. V. 13, N. ${ }^{\circ}$ 1, 2015, p. 216-246.

TU, Shine - Patent, Examiners and Litigation Outcomes. In Stanford Technology Law Review. Stanford. ISSN 1098-4267. V. 17, 2014, p. 507-548.

VAHEESAN, Sandeep - The Evolving Populisms of Antitrust. In Nebraska Law Review. Lincoln. ISSN 0047-9209. V. 93, N. ${ }^{\circ}$ 2, 2014, p. 370-428.

WASSERMAN, Melissa F. - What Administrative Law can Teach the Trademark System. In Washington University Law Review. St. Louis. ISSN 2166-8000. V. 93, N. ${ }^{\circ} 6,2016$, p. 1511-1575.

WEILBAECHER, Ann - Diseases Endemic in Developing Countries: How to Incentivize Innovation. In Annals of Health Law. Chicago. ISSN 1075-2994. V. 18, N. ${ }^{\circ}$ 2, 2009, p. 281-309. 